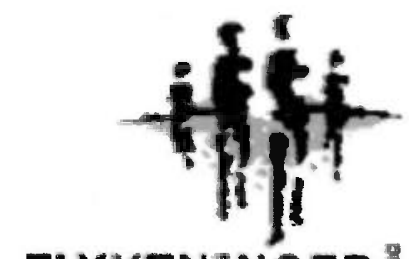

FLYKTNINGERÅDET

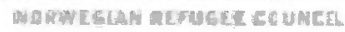

\author{
AFGHANISTAN
}

\title{
LAND AND PROPERTY \\ DISPUTES
}

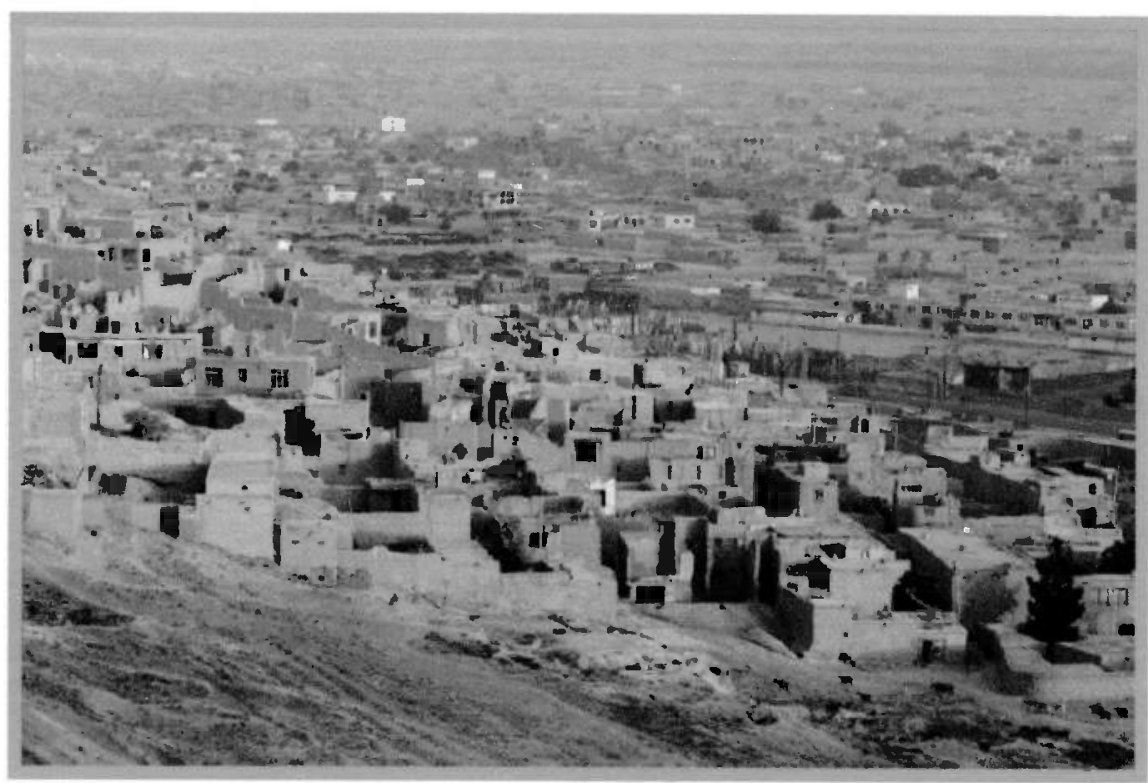

IN EASTERN AFGHANISTAN

By Conor Foley

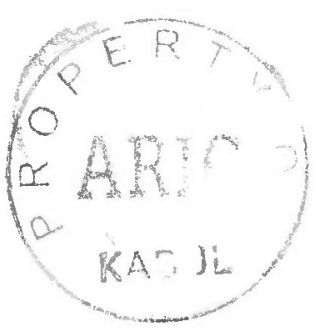


L and disputes remain a major cause of tension and instability in eastern Afghanistan and pose a significant threat to peace, security and the rule of law. It is widely recognized that this continued instability is an obstacle to sustainable return. This report is based on cases registered in the provinces of Nangarhar, Laghman, Kunar and Nuristan by the Jalalabad Information and Legal Aid Center (ILAC), which was established by the Norwegian Refugee Council (NRC) with support from the United Nations High Commissioner for Refugees (UNHCR) and the Norwegian Ministry for Foreign Affairs (MFA) in March 2003. The project continues in 2004 with support from the European Communities Humanitarian Aid Office (ECHO), the Norwegian MFA and UNHCR.

NRC's information and legal aid program is based on a belief that the provision of free legal assistance can make an effective contribution to creating conditions conducive to sustainable return. By helping individuals to assert their rights, NRC's legal counselors are also challenging many of the underlying problems that give rise to land disputes.

This report gives an overview of some of the land and property disputes in eastern Afghanistan. Between March 2003 and April 2004 NRC's Jalalabad ILAC registered over 200 cases related to land and property disputes. This is only a small proportion of the total number of such disputes in Nangarhar, Laghman, Kunar and Nuristan and the cases that are outlined in this report are only a small, but representative, proportion of NRC's current case-load. The purpose of this report is to provide a more detailed picture of the nature and extent of the problem of land disputes in eastern Afghanistan, to show how it is currently being dealt with and to offer some proposals for reforms.

\section{THE UNDERLYING CAUSES OFLANDAND PROPERTY DISPUTES}

he main causes of land disputes in Afghanistan can be summarized under the following headings:

* Conflict. Since the invasion by the Soviet Union in 1979 Afghanistan has experienced 25 years of almost continual conflict that has caused millions of people to flee from their homes. During their absence, these people's land and property was often occupied, or bought and sold and now, as they return home, they are demanding its restitution.

Regime changes: Successive governments have violently replaced one another over the last 30 years and different regimes have pursued different land policies, often based on rewarding their own supporters through favourable land allocations.

Unclear oumership. The unorganized land registration system, the large number of missing title deeds, and the fact that disputed land has often been sold many times over, makes it very difficult to determine who owns what.

- Reliance on customany documents and mechanisms: Many land and property transactions take place without being officially approved by the courts, using customary documents or traditional dispute resolution mechanisms, such as Shura and Jinga.

Land shortage: Only 12 per cent of the land area of Afghanistan is suitable for arable farming. A further 45 per cent is currently being used as pastureland by both settled and nomadic farmers, but tenure arrangements over pastureland are often unclear and disputes are frequent. Land 
pressure is exacerbated by Afghanistan's high birth rate and the rapid return of so many refugees in 2002 .

Landlessness: A large number of people in Afghanistan have no land and when they return back from exile they sometimes occupy other people's land, or government-owned land because they have nowhere else to go.

Tribal and ethnic disputes. Competition for scarce resources, such as land and water, is often linked to ethnic or tribal tensions or to other political conflicts.

Comuption: There are numerous reliable reports that members of the judiciary and executive organs are abusing their positions for personal or political interests, or due to pressure exercised by other powerful members of society.

\section{Lace of a mule of law: Even where the} courts, public authorities or customary dispute resolution mechanisms issue fair decisions there is no guarantee that these can be enforced. A large number of powerful commanders, and their supporters, consider themselves to be 'above the law' and the lack of an effectively functioning legal system means that many people rely on the use of force to settle disputes.

As the above list indicates, the problem of land disputes cannot be dealt with in isolation from tackling Afghanistan's other problems. Clearly there are also no 'quick fixes' to the problems described below. Indeed attempts ato impose solutions from above may actually be counter-productive, as the creation of new laws, commissions and other institutions may only add to the existing confusion and make it harder to strengthen and reform the mechanisms that already exist. Where the international community can perform a valuable role is in monitoring these institutions and measuring their claims against their practical performance.
Peace and stability are obvious pre-requisites for tackling the problem of land disputes. A strengthening of the rule of law, building the capacity of existing institutions and tackling corruption are also vital. Land reform is a controversial subject in Afghanistan today, but the problem of land disputes is clearly linked to the inequitable system of land ownership and the huge, and growing, number of landless people. Without a coherent policy of land reform it is difficult to see how many of the grievances which continue to promote tribal, ethnic and political conflicts will ever be successfully addressed.

Establishing who are the legitimate owners of land and property in a country such as Afghanistan is, obviously, a huge task, but the provision of free legal aid provides one mechanism for doing this. Although land rights in Afghanistan are governed by a number of different regimes - customary law, civil law, religious law, State law and constitutional law - these do share some common principles when it comes to assessing competing claims.

The reliance on customary documents and mechanisms - such as Shura and Jinga - also poses a challenge, but, given the current lack of capacity and widespread corruption that exists within the official system, these bodies are potentially extremely useful mechanisms for settling disputes.

Shura and finga are products of Afghanistan's patriarchal, tribal society, which lays a strong emphasis on solving conflicts 'privately', within the family, village or clan. A Jinga is a decision-making forum at which, theoretically, all adult males can participate. A Shura is restricted to the elders of a particular community. While Shura and Jinga claim to base their decisions on principles of Islamic law, their perceptions of what is law is influenced heavily by Afghan tribal traditions.

Since Shura and finga reach decisions by consensus, they tend to try to settle disputes through compromise. This makes them an effective mechanism for conflict resolution. However, they do not always offer the best method of upholding individual rights. 
Women rarely have any say in their deliberations, and may find their own rights being violated by the settlement reached. Traditionally, it was common to offer a girl from one family to another as part of a settlement as this was seen as a means of uniting two families and also providing the injured party with a potentially valuable source of dowry income.

The informal nature of the proceedings at Sbura and Jinga also mean that they are open to manipulation. 'Dispute is a fruitful tree' according to an Afghan proverb and people sometimes exaggerate their claims before going to a Shura or Jing in the expectation that they will be expected to bargain down from this position to reach a final settlement.

There is also some evidence that powerful commanders have used these mechanisms to legitimize their own actions and to increase their influence in a particular area.

Nevertheless, Sbura and Jinga derive their legitimacy from their perceived ability to settle disputes and both have a long history of resolving land disputes throughout Afghanistan. At their best, they are the closest thing to democratic institutions in the country today. They can reach decisions much faster than the official courts, are virtually cost-free, are less susceptible to bribery and are accessible to illiterate Afghans.

Afghanistan's legal system is based upon principles of Islamic law and both the courts, on the one hand, and Sbura and Jinga, on the other, formally base their decisions on Shari'a law. Although Shura and Jinga are not officially recognized within the Afghan legal system, judges often instruct two parties to a dispute to first try resolving his or her differences through this mechanism. If either side is not satisfied with the decision reached by one of these bodies, that person may still pursue their case through the official court system. NRC's counselors, and most Afghan lawyers, therefore, usually attempt to exhaust mediation in this way before bringing a case to court. Given the current lack of a rule of law this is as much due to necessity as choice.
T he following cases are intended to provide a snap-shot of the problem of land disputes in Nangarhar, Laghman, Kunar and Nuristan. Some of them have been solved, but the majority remain unresolved at the time of publication. The names of individual clients have been omitted for reasons of confidentiality, but the names of places, groups or leading figures, that are already in the public domain, have been included.

The dates given in this report are as accurate as possible, but, as many Afghans are illiterate, they are often unable to give precise dates for when they bought land, left the country or returned to the country from exile. NRC's Jalalabad ILAC is based in Nangarhar so most of the cases are from this province. The provinces of Kunar and
Nuristan are largely inaccessible, on security grounds, and so NRC's Jalalabad ILAC has registered very few cases from either province. It is likely that the situation there is considerably worse given the lack of any effective rule of law.

Where possible NRC's legal counselors have spoken to both sides in the dispute, but the accounts below are largely based on the testimony of NRC's own clients. Some of NRC's clients are clearly terrified of the parties opposing them in disputes and NRC's counselors have been physically threatened on some occasions due to their involvement in these cases. Given the conditions that exist in Afghanistan at the moment, it is very difficult to produce a rigorously impartial, referenced and cross-checked report, but every effort has been made to ensure that the 
following accounts are as truthful and accurate as possible.

\section{TANGI TOKHCHI}

In 1973 the people of Tangi Tokhchi village, in Behsood District of Nangarhar Province, were awarded 274 Jerib of land by Decree Order No 720 of H.M King Zahir Shah. This land was divided up by the revenue department (IMI.AC) to 22 families and each family was issued with a copy of the presidential decree awarding them ownership.

King Zahir Shah was overthrown in a military coup in 1973 and General Daoud became President. During this time the villagers built 22 houses on some of the land and began planting crops and trees. They claim that they paid taxes during this period, but were unable to obtain full legal documents (in Persian: Qabala) proving their ownership of the land as President Daoud had banned any more from being issued. However, in 1977 Afghanistan adopted a new Civil Code, which is based upon and replaces the previous Mujalat ut Abkam al- Shari'a. Article 965 of Volume 4 of the 1977 Code states that if a person occupies government-owned land with official permission, uses this for productive purposes, and pays taxes for over 15

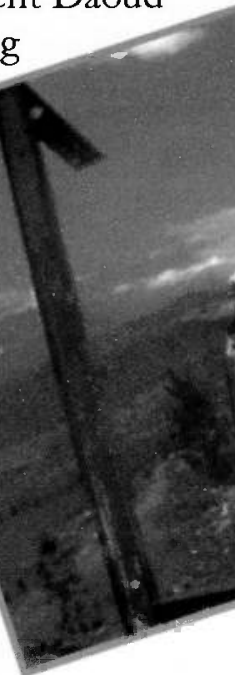
5 years, then the property on the land reverts to that person's ownership.

In 1978, General Daoud was overthrown in another military coup, and the new Communist Government embarked on a policy of land reform in which it sought to break up large landholdings and re-distribute land to the poor. This policy was extremely controversial and helped to prompt the revolt, which almost toppled the regime.
In 1979 the Soviet Union invaded Afghanistan and a new Decree was issued telling people to re-register their land and stating that those who did not have a valid Qabala could have their land taken back by the Government. The people of Tangi Tokchi registered their land and obtained Qabala in 1983.

In 1992, the Soviet-backed President Najibullah was overthrown by the Mujabedin and a new Government was established under President Rabbani. This issued a Decree stating that the previous Government's land transfers were illegal and should be reversed. The new Government would therefore not recognize land ownership documents issued by the previous regime. A subsequent Decree clarified that only the seizure and redistribution of private land was illegal. Where Government-owned land had been given to people these transfers remained lawful.

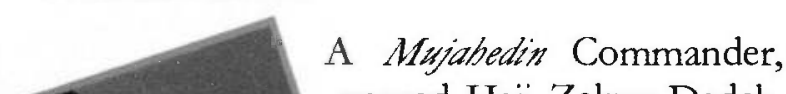
named Haji Zalmy Dadek, was appointed Sub Governor of Behsood District in 1992 and he confiscated the land of the people of Tangi Tokhchi village, saying that it belonged to the Government and that their Qubalas were not valid, as they had been issued under the Communist administration. $\mathrm{He}$ also accused the people of having not supported the jithad against the Soviet Union. Bulldozers demolished their houses and some of the elders from the village were briefly imprisoned.

The people of Tangi Tokhchci appealed to the Governor, Haji Qadir, over Zalmy Dadek's head, but he told them that there was nothing he could do. The villagers claim that he took copies of their legal documents for reference, but subsequently burnt them. Most of the villagers left the country between 1992 and 1995 and went into exile in Pakistan. 
In 1995 the Taliban captured Jalalabad and Zalmy Dadek fled into exile along with most other Mujahedin commanders. The people of Tangi Tokhchci returned to Afghanistan and took their case to the Primary Court. The courts had been instructed by the Taliban to no longer apply the 1977 Civil Code, but to instead revert to the Mujalat ut Ahkam at Shari'a. Nevertheless, the Court ruled that the land belonged to the villagers and they were able to reoccupy their land. In 1996, the villagers claim that Zalmy Dadek's brother returned to Afghanistan and used his influence to persuade the Court to reverse their previous decision and decree that the land belonged to the State. The villagers refused to leave, and four of their elders were again briefly imprisoned. They appealed against the ruling to the Supreme Court and this ruled in their favor in 2001, a few months before the fall of the Taliban regime.

In December 2001, Zalmy Dadek returned from exile, after the fall of the Taliban, and he was appointed Sub Govemor of Khawa, a neighboring District to Behsood. Zalmy Dadek again claimed possession of the land of the people of Tangi Tokhchci, this time stating that he had legal documents, proving his ownership of it. The people of the village claim that these documents are forgeries. Despite the ruling of the Supreme Court that the land belonged to the villagers Zalmy Dadek occupied the land.

The villagers appealed to the new Sub Governor of Behsood District to intervene. He referred the case to the Primary Court in 2002. This finally came to a decision in 2003 , but, instead of ruling on the case, it referred the case back to the Sub Governor of the District, blocking the villagers from being able to appeal to the Provincial High Court. The Sub Governor's office has since maintained that no further action can be taken unless there is a further order of the Court, while the Court insists that the case is now out of its hands.

Around 20 families of Tangi Tokhchi village are still living in their homes, but are unable to farm. Another 30 families are now living in internal displacement in Jalalabad City or as refugees in Pakistan. The case, therefore, involves about 500 people.

In June 2003, the villagers appealed to Jalalabad ILAC for help in dealing with their case and NRC's legal counselors have had a number of meetings with the court, the Sub Governor's office and Zalmy Dadek. Jalalabad ILAC has attempted to persuade both the courts and the provincial administration to refer the case to the High Court. Attempts have also been made to settle the case by a Jirga. Unfortunately, all of these attempts have been unsuccessful.

NRC's Jalalabad ILAC have examined Zalmy Dadek's documents, which he claims prove that he owns the land, and have consulted the IMLAC land registry. NRC's legal counselors are satisfied that these documents are not legally valid and that the people of Tangi Tokhchi village are the real owners of the land.

NRC basis this opinion on a number of points. As well as possessing valid Qabalas the villagers possess a copy of Decree Order No 720 from H.M. King Zahir Shah, which awards the land to them, and copies of the previous court decisions, which also ruled in their favor. In addition to this, they have lived on the land for more than 15 years and so have established a right to ownership under Article 965 of the 1977 Civil Code. Finally, the refusal of the Primary Court and the Sub Governor's office to make a clear decision which would allow the case to be referred to the Provincial High Court violates Article 5 of the Islamic Transitional Authority (ITA) Decree on Dignified Return, issued in December 2001, which states that all moveable and immovable property shall be retumed to its rightful owner as determined by the relevant legal organs.

In February 2004, NRC's legal counselors, along with representatives of UNHCR and the UN Assistance Mission in Afghanistan (UNAMA) met the Deputy Governor of Nangarhar province and requested him to intervene directly to ensure that the case was referred to the courts. This case has since been referred to NRC's office in Kabul. 


\section{SHAHIDAN AND KARELYKAS}

Shahidan is located in west of Qarghay District of Laghman province, 47 kilometers west of Jalalabad. There are approximately 400 families living in the village and another 200 families are still waiting to return from Pakistan. The village has about 600 Jeribs of land and is connected by a bridge to the Kabul-Jalalabad road. The bridge is damaged and the village has no school or health center.

The neighboring village of Karelykas is about 4 kilometers further back from the main road. It has even fewer basic services and water is extremely scarce there. 'Not even a bird could find a drop of water there in the summer' one village leader told an NRC legal counselor.

The people of Shahidan and Karelykas are from the same ethnic and tribal group. Both fled Afghanistan for Pakistan during the 1980 s and both began to return in late 2001 . A large number of the people of Karelykas are landless Internally Displaced People (IDPs) and 75 families were settled on government-owned land near to Shahidan in 2003. They were granted official permission to settle on this land but the people of Shahidan object to their presence and claim that the land is needed to build new homes as well as a school and clinic. They say that many people from the village are still in exile in Pakistan and that they need the land to accommodate these new arrivals. The Karelykas IDPs say that the police have threatened forcibly to evict them. NRC's legal counselors have met the Head of the Police in Laghman province and he denies this accusation.

The Karelykas IDPs say that they cannot return to their own village as it has no water or basic facilities such as a school or health clinic. It is also extremely far from the main road. They may be willing to retum if such facilities were provided, but they would need to be granted official titles to land in their own village as the land is also governmentowned. The Karelykas IDPs are also willing to move elsewhere, if suitable land can be allocated to them, but they also claim that some of them do own land in Shahidin village and have the legal ownership documents to prove it. The people of Shahidin village reject this claim.

UNHCR and NRC's legal counselors had a number of meetings with both the Karelykas IDPs and the Shahidin villagers during January and February 2004. The counselors also met with the Government in Lagman Province, including the Governor, the Head of the Police and the law department. UNHCR and NRC are attempted to mediate a settlement to the case as they are concerned that the dispute could escalate and even lead to conflict between the two groups. Both sides in the dispute are heavily armed and there have already been a number of confrontations in which they have threatened one another with weapons. On one occasion, during one visit by UNHCR Protection staff a verbal clash between the two groups quickly escalated and several hundred fighters emerged to threaten one another with automatic weapons and Rocket Propelled Grenade (RPG) launchers.

In a meeting with NRC and UNHCR in February 2003, the Governor of Laghman province expressed the view that the case could best be solved through transferring the Karelykas people to a new settlement that he is proposing to construct in Surkhakan District which could hold up to 4,000 families in Microrayan-style apartments. However, the central Government in Kabul has yet to grant permission for the construction of this settlement and it may be difficult to attract the donors necessary to fund this ambitious project. Even if the settlement is constructed this could take several years and so it is could not offer a short, or medium, term solution to the problem.

The Karelykas IDPs told NRC's counselors that they are not interested in moving to Surkhakan, as they believe that the apartments will be too small for their families. They are prepared to return back to their original village, or to settle elsewhere, but only if they are granted official 
permission by the authorities and are provided with some humanitarian assistance to improve the conditions of life wherever they settle. Humanitarian agencies are unable to provide such assistance unless the Government provides official permission for them to settle on new land and, without such permission, the Karelykas people believe that they will be vulnerable to future harassment.

In March 2004 the Karelykas IDPs moved to another area, in Gandas, which is to the west of Shahidin. However the Shahdin villagers also object to their presence there. The condifions in which the IDPs are living are clearly inadequate and exposed to the elements. A number of people have fallen ill. There is also a continuing potential for a violent clash between the IDPs and the Shahidin villagers.

The central Government in Kabul has currently banned any further allocations of land and, without a new decree, it may be impossible to find a solution to this dispute. After pressure from NRC and UNHCR, in June 2004, an official comission recognised the right of the people of Karelykas to stay in Gandas.

\section{CASE 3 \\ HASARK DISTRICT}

In 1978, four brothers bought $5 \frac{1}{2}$ Jeribs of land, in Hasark District of Nangarhar province and have customary (i.e. unofficial) documents to prove it. They farmed this land for six years from 1978 to 1984 , when they fled Afghanistan for Pakistan. While they were in exile their land was occupied by a Mijabedin commander named Marrany, who is the younger brother of the original owner, and who installed his own farmers on the land. Many men of fighting age left Afghanistan during the 1980s, either to avoid being conscripted into the Afghan Army, or to join the Mujahedin in their jihad against the Soviet Union. Consequently, most of the people that remained to farm the land were elderly men, women and children and those men who had completed their national conscription.

From the mid-1980s onwards, as the influence of the Communist Government in Kabul weakened, many parts of Eastern Afghanistan, including Hasark District were effectively under the control of the Mujabedin. Commander Marrany is the cousin of Haji Qadir and 
case should be settled through a Jinga. An attempt was made to settle the case through a Jinga, but this proved unsuccessful and Haji Qadir established a commission to investigate the problem in 1995. On the day that this commission was due to issue its report, the Taliban captured Jalalabad and Haji Qadir, and other members of the previous administration fled to Pakistan. Both Commander Marrany and the four brothers also fled the country. Commander Marrany went to Germany and the four brothers went to Pakistan.

When the Transitional Govemment came to power, in 2001, Commander Marrany returned to Afghanistan and took control of the land. He has offered the four brothers some money, but is refusing to leave the land and claims that he is the rightful owner. $\mathrm{He}$ argues that his elder brother did not have the right to sell the land without his agreement, as the land was inherited from his father and belonged to both brothers.

NRC's legal counselors have taken up this case as it believes that the four brothers are the rightful owners, based on the fact that they have customary documents and that they have previously been recognized as the rightful owners by the former Governor of Nangarhar. However, the security situation in Hasarak District has prevented NRC's counselors from visiting the area to attempt to resolve the dispute.

\section{GHANI KHAIL DISTRICT}

NRC's client has three brothers and they each inherited $1 \frac{1}{2}$ Jerib land in Ghani Khail District, Nangarhar province, from their father. One of the brothers borrowed some money from a group of seven local people and subsequently defaulted on the loans and left the area. The creditors demanded that one of the other brothers, whom NRC is now representing, produce his brother or give them his house and land or the money that this brother owes them.

The case was registered at NRC's Jalalabad ILAC in August 2003. The following month, in September 2003, another of the brothers was arrested by Commander Nowshar, the Head of the Police in the District, and was told that he should surrender the house and property to the creditors. He was held in Ghani Khail Police station for three days in an attempt to pressurize him to hand over the house and land.

NRC's counselors met with Commander Nowshar and asked him what was the legal basis for this arrest. They were told that there is a customary rule in the District that if one person borrows money from someone then other family members are also responsible for the debt. This rule has no basis in Afghan law and so the police's actions appear to have been illegal.

NRC's counselors convened a meeting with Commander Nowshar in Ghani Khail District, together with the client and the creditors. As a result of this meeting an informal settlement was agreed, where the clients agreed to sell part of the land in question in order to repay the debt.

\section{STREAM ELEVEN}

\section{BEHSOOD DISTRICT (1)}

In 1983, the Communist government awarded six Jerib of government-owned land to a man living in Behsood District of Nangarhar. The land is beside the eleventh of the fifteen streams that run through Nangarhar province and that are commonly used to identify locations. The man received the legal title to his land and an official Qabala.

In 1992, a Mujabedin commander named Qumandan, from the Hizb-i-Islami faction, seized the land claiming that he had been allocated that land as part of 11 Jeribs that he was awarded in 1976. Commander Qumandan further claimed that the distribution carried out under the previous regime was illegal and that he was the real owner of the land.

Other people living in the same area also had their land confiscated by people allied to Mujahedin factions and NRC is currently 
pursuing very similar cases on behalf of a number of other clients. All were allocated between four and six Jeribs of land under the Communist Government, which was then confiscated under President Rabani's regime. Where this was previously governmentowned land it should have been restored to them, but due to the lawlessness that characterized the period 1992 - 1995 this often did not happen.

NRC's client in this particular case left Afghanistan for Pakistan and did not retum until 2001, after the fall of the Taliban. Commander Qumandan remained in possession of the house and land throughout this period.

Between 2001 and 2003, the man made several attempts to resolve the case through the courts before appealing to NRC's Jalalabad ILAC for help. In October 2003, NRC's counselors met with officials of the provincial IMLAC who confirmed that their client's documents are valid and that Commander Qumandan has not produced any legal documents to support his claim. NRC's counselors also met with the District courts in November 2003, in an attempt to resolve the issue. In March 2004 the courts requested that the IMLAC to examine its records again and this time a District official stated that Commander Qumandan was registered as the owner of the land. NRC's counselors believe that this entry is a forgery that has been made after the start of the current legal proceedings. The case remains unresolved at the time of writing.

\section{BOLON VILLAGE}

In 1995 a man from Bolon village, in Qaraghey District, Laghman province, died and left his land to his four children as an inheritance. He had owned 10 1/2 Jeribs of land and he divided nine of these Jeribs between his three sons while leaving $1 \frac{1}{2}$ to his daughter.

His daughter, NRC's client, had left Afghanistan for Pakistan three years previously and so the family agreed that this land would be sub-let to another person who would farm the land in her absence and pay her rent from the produce. In January 1996, this agreement broke down when one of her brothers occupied her land, arguing that, as a woman, she had no right to such an inheritance and that he was therefore claiming ownership of it.

The woman returned to Afghanistan after the fall of the Taliban and appealed to NRC's Jalalabad ILAC for help. NRC's counselors helped her prepare a legal document and represented her at a finga in Bolon village, where the case was solved through mediation between the client and her brothers, facilitated by a village elder. Her brother agreed to return her land and she agreed to waive her right to the lost income from the years in which it had been occupied.

\section{STREAM NUMBER SEVEN BEHSOOD DISTRICT}

In 1984, the Government awarded six Jeribs of land, in Stream Number Seven, Behsood District, Nangarahar province to the father of NRC's client. After he died he passed on this land in an inheritance to his son who has the Qabala for the land.

The family left Afghanistan in 1992, when the Mujahedin came to power, and leased the land to someone else. In 1997, another man took possession of the land, claiming to be the real owner. When NRC's client returned to Afghanistan in 2003 this man refused to return it saying that the Qabala was not valid as it had been issued under the Communist regime and that the land had originally belonged to him. He also claimed to have legal ownership documents.

NRC's legal counselors in Jalalabad examined both sets of documents and then referred the case to NRC's ILAC in Kabul. NRC's legal counselors in Kabul investigated the central Government's records of land ownership and found that the second man was registered as the original owner of the land. This land had been taken from him by the Government in the $1980 \mathrm{~s}$ and re-distributed. Such re- 
distributions of private land have since been declared illegal and so NRC's legal counselors concluded that their client's claim was invalid. The client accepted this advice and dropped his claim to the land.

\section{TORKHAM}

In 1995, the Taliban government granted permission to NRC's client to build a shop on government land in Torkham, in Nangarhar province, on the AfghanistanPakistan border. The man was given official written permission by the District Authorities and has all the necessary official legal documents. He paid taxes to Torkham Municipality and has the receipts for seven years of payments.

In March 2003, a local commander, named Inam Shah, tried to forcibly occupy the shop, claiming that it belongs to him. Commander Inam Shah claims that in 1992 he was awarded ownership of the land on which the shop has been built by the then Governor, Haji Qadir. Commander Inam Shah claims that he has a letter from Haji Qadir awarding him ownership of the land and that this was granted as part of a settlement to a tribal dispute between the Mohmand and Shinwar tribes. These two tribes straddle the AfghanPakistan border and dominate the Districts of Nangarhar. Both claim ownership of the land in these areas and Commander Inam Shah has told NRC's legal counselors that the Governor took action to prevent a clash between them. Commander Inam Shah belongs to the Mohmand tribe and he says that the Governor allocated him this specific plot of land as it lies within the land allocated to the Mohmand people and because he had fought in the jithad under Haji Qadir's command.

Commander Inam Shah was forced to flee Afghanistan to Pakistan when the Taliban occupied Jalalabad in 1995, but says that he is the real owner of the land and that he had sent messages to NRC's client informing him of this. Commander Inam Shah returned to Afghanistan after the fall of the Taliban and he is now Head of the Second Region Police
Station in Jalalabad and reports to Haji Zahir, Haji Qadir's son, who is the Commander of The Afghan Border Security Force (a military unit that reports to the Ministry of the Interior rather than the Ministry of Defence).

When this dispute was first reported, Torkham Municipality attempted to seal access to the shop by both parties, until the dispute was settled, but Commander Inam Shah simply broke the locks and threw out all of the belongings of NRC's client.

NRC's legal counselors have had a number of meetings with both sides in this dispute. NRC's legal counselors have asked to see a copy of the letter which Commander Inam Shah claims to possess, awarding him the land, but he has not yet produced it. NRC's legal counselors have also contacted Torkham Municipality who have confirmed that the documents produced by their client are genuine and that he has been paying taxes for the period that he claims.

NRC's legal counselors believe that, even if Commander Inam Shah does have a letter from the previous Governor, this is not sufficient proof of ownership as this document has not been registered with the Municipality or any government department. On the third occasion that NRC's counselors met with Commander Inam Shah he said that he had submitted the case to a finga, but subsequent investigations proved that this was untrue as the mediators that he claims have been appointed both deny this. This case remains unresolved at the time of writing.

\section{BATIKOT DISTRICT}

In 1970, the grand-father of NRC's client received 7 Jeribs land by decree of King Zahir Sha, in Canal stream number 26 in Batikot District of Nangarhar province. In 1976 he built a house on government-owned land that lies next to the land that he was awarded. This land was previously desert and the total area that he took amounts to 4 Jeribs of land. He stayed in his house until 1980 when he went Pakistan, leaving some members of his 
family behind to take care of the house and land.

In 1996, a neighbor took a case against NRC's client in Behsood Primary Court stating that the land belonged to him. He produced documents which NRC's client has stated are forgeries. The Court and IMLAC departments both sent delegations to investigate the land in question and these concluded that the house was built on government-owned land. Because NRC's

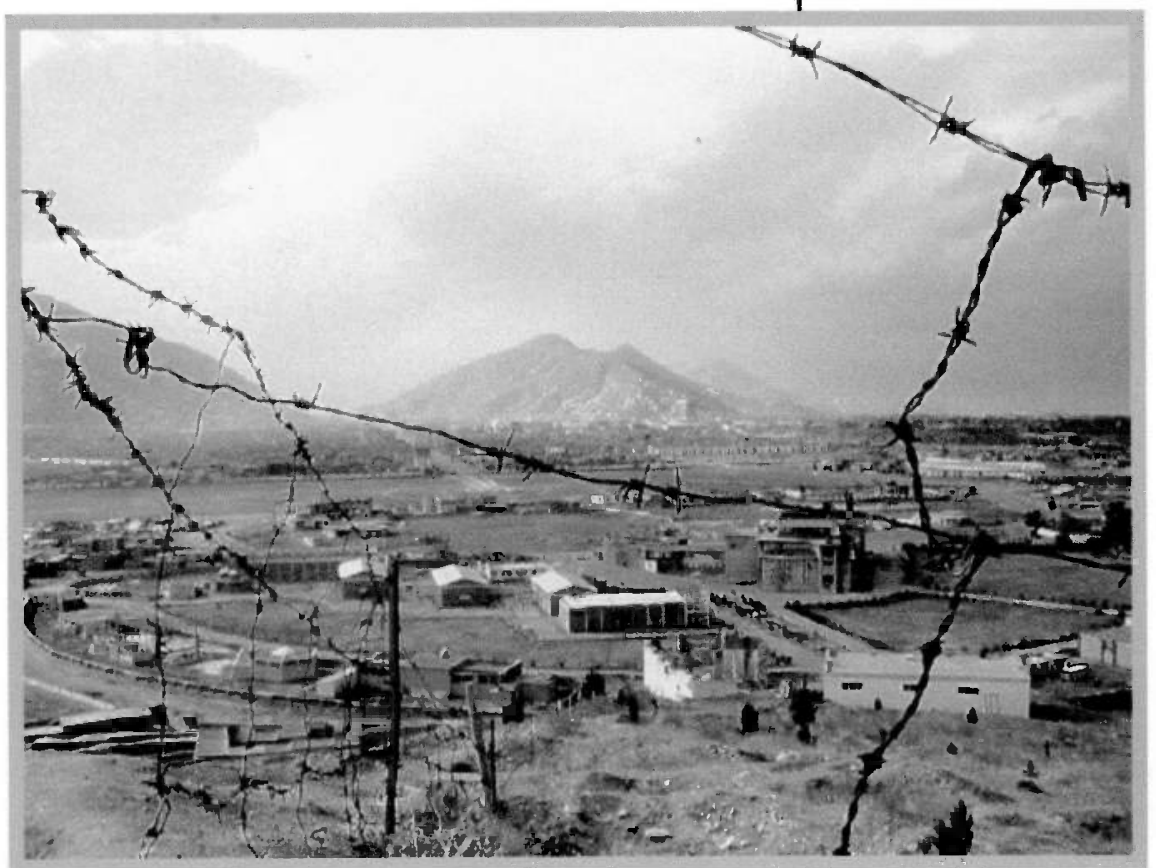

client had occupied the land on which the house was built for over 15 years he had established a right to ownership of it under Afghanistan's civil code. The Taliban regime, which was in power at the time, had recently re-confirmed this and issued a Decree stating that people who were occupying government-owned land could remain there if they paid rent to the Govemor, so NRC's client paid $15 \mathrm{~kg}$ of wheat per year in rent to formalize his occupation.

In 2002, the man who had complained against NRC's client took another case to the administration of Batikot District claiming that, as the house was built on land that bordered his own land, he should be awarded ownership of it. The case was referred to a Jinga and this decided that the house belonged to NRC's client and drew up a customary document for both sides to sign. The other man refused to accept this decision and appealed again to Batikot District administration. The case remains unresolved at the time of writing.

\section{CASE 10 \\ JALALABAD CITY}

NRC's client is a policeman who bought a house in 1985 in Jalalabad city in which he lived until 1992. The purchase was lawful and he still has an official Qabala proving his ownership of the house and land.

In 1992, during President Rabani's regime, a Mujabedin commander named Zyarat Gull, the son of Sar Gull, a leading member of Hiqb-i-Islami, seized the house saying that the policeman was a communist and so his property was forfeit. Commander Zyarat Gull said that he would kill the man if he attempted to return. The man appealed to different government departments, but was unsuccessful.

In 1995, when the Taliban arrived, Commander Zyarat Gull fled and the man returned to his house and reoccupied it. $\mathrm{He}$ then rented it out to another person and returned to Pakistan where he lived until 2001. After the fall of the Taliban the man came back to Afghanistan and resumed his job as a policeman, but he found that Commander Zyarat Gull had also returned and was again living in the house. Zyarat Gull had been appointed Head of Military Division Number Seven of the new Afghan National Army.

NRC's client reported to the police that he was the lawful owner of the house on a number of occasions, but without success. In March 2003, the man claims that he was kidnapped by two men, Commander Zyarat Gull and another Commander named Kalo, who is responsible for security in Jalalabad 
airport. NRC's client claims that he was taken to the airport and placed in a dark detention room where he was held for three days in an attempt to pressurize him into dropping his case. He was only released after the Head of the Police in Jalalabad city intervened in the case. No action was taken against either of his two alleged assailants.

Commander Zyarat Gull has since sold the house to another man, Haji Mosa, who is the brother-in-law of Hazrat Ali, the Corps Commander of Nangarhar province. The case remains unresolved at the time of writing.

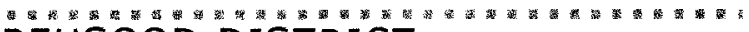

BEHSOOD DISTRICT

NRC's client owned 6 Jeribs of land in Behsood District, Nangarhar province, which he inherited from his father. $\mathrm{He}$ has customary documents to the land, but no Qabala. In 1978, he left Afghanistan for Pakistan and leased four Jeribs of land to a person called Gholam Dastagir. The rest of his land he left in the care of his relatives.

In 1991, while he was in Pakistan a rumour spread that he had died and so his relatives divided his land between them. His tenant, Gholam Dastagir, also died at around the same time and his son-in-law, a Mujabedin soldier, took the land. Hearing this, NRC's client returned to Afghanistan in 1992 and attempted to regain his land. However, the Mujabedin soldier produced documents, which he claimed proved that the land belonged to him. NRC's client claims that these documents were forged but that the Mujabedin soldier rèfused to either hand back the land or submit the case to mediation. The Mujahedin had seized power in 1992 and so NRC's client did not feel able to challenge the soldier.

NRC's client was afraid to take any further action, even after the fall of President Rabani's regime in 1995, when the Taliban came to power. After the fall of the Taliban in 2001, he began legal action to recover his land. Unfortunately he does not have any legal documents and so when the case came to the Primary Court in 2002 he was unable to prove his ownership of the land. The judge asked him to produce witnesses to swear that he was the owner of the land, but the man had failed to bring any as, he claims, the other villagers were too scared to testify on his behalf. Under Afghan law, in a civil case, if the plaintiff in a case cannot satisfy the burden of proof to justify his complaint the judge will normally uphold the status quo. The former Mujabedin soldier swore that the land belonged to him and also produced two witnesses to testify that it was his. Consequently the judge ruled in favor of the former soldier.

In August 2003, the man appealed to NRC's Jalalabad ILAC for help and NRC's legal counselors helped him to prepare his case for appeal to the Secondary Court. Since he commenced his legal action NRC's client claims that he has been threatened on several occasions by the former Mujabedin soldier. He says that he was beaten up on one occasion and thrown into a river where he almost drowned. NRC's legal counselors have seen the injuries that he claims he suffered in one attack and have asked the Attorney-General's Department to investigate these alleged incidents. The case remains unresolved at the time of writing.

\section{MOHMANDRA DISTRICT}

NRC's client owned 6 Jeribs of land in Mohmandra District of Nangarhar. He left Afghanistan for Pakistan during the conflict and while he was away another man occupied his land. On his return in 2003, the man who occupied the land refused to vacate it saying that he had planted that year's crop and had worked the land for six or seven years and so deserved the crops for that year's harvest

NRC counselors organized a Jinga, which decided that the occupant of the land will take the income from that year's harvest, as compensation and will then prepare the land for next season's sowing and hand back the land to NRC's client. Both sides were satisfied with this solution. 


\section{SAMAR KHAIL}

NRC's client inherited $8^{3 / 4}$ Jeribs of land in Samar Khail village of Behsood District, Nangarhar province some time between 1973 and 1976. The family left for Pakistan shortly after the Soviet invasion of Afghanistan in 1979 and remained there until 2003.

When the family returned they found that two powerful commanders: Hedar, who is in charge of customs in Jalalabad, and his brother Abdul Khaleq, a commander in Bagram, had occupied 1 Jerib of their land and were threatening the family to prevent them from building a house.

NRC's legal counselors contacted the IMLAC Department and were informed that the land does belong to NRC's client. In October 2003, NRC's legal counselors went to the client's place and met with the elders, the two commanders and a representative of the village. A finga was convened and both sides agreed to accept the result. The Jinga decided that the land should be restored to NRC's clients, but that the client should pay the cost of tools and materials that the two commanders had brought onto the land themselves. Both sides agreed with this decision and as a result the case was resolved through mediation.

\section{MOHMANDRA ENCASHMENT CENTER}

NRC's client claimed that his uncle defrauded him of inherited land and property, using a forged document, and that he had also been falsely accused of kidnapping his cousin. NRC's client had received a three-year prison sentence for this alleged kidnapping, but claimed that this was because his uncle had bribed the judge and local public officials. NRC's client left Afghanistan, for Pakistan, and, on his retum, succeeded in having the kidnapping charge quashed at the Secondary Court. The client approached Jalalabad ILAC for help in resolving the dispute.
After a number of attempts, Jalalabad ILAC succeeded in convening a finga in the ILAC office at which both sides agreed to settle their dispute by withdrawing charges and accusations against one another. This dispute was settled in the presence of a number of village elders and the settlement has been registered with the District Administrator.

\section{CHARBAGH VILLAGE}

In 1994, NRC's client entered into a landlease contract with another private individual. The contract concerned 2 Jerib land owned by NRC's client in Charbagh village, Surkhroad District in Nangarhar province.

In 1996, NRC's client decided to terminate the contract and demanded his land back. The other man refused, claiming that NRC's client had sold him the land, and produced a document supposedly proving this. NRC's client claims at the time that there had been no such sale, and that the signature on the sales contract is a forgery. He pointed out that the document did not have an official stamp on it, nor any signatures of witnesses.

NRC's client complained to the provincial authorities who referred the case to Surkhroad Primary Court in 1997. When the case was heard in the Primary Court, the judge found in favor of the other man. NRC's client claims that the judge had been bribed and he appealed to the Secondary Court, which found in his favor. Before this court decision could be implemented, the war between the Tatiban and coalition forces started in 2001, forcing NRC's client to flee to Pakistan. He has since returned and now wants to take possession of his land.

NRC's legal counselors are now attempting to convene a finga between the two sides to convince the other man to abide by the Secondary Court's decision. The case remains unresolved at the time of writing. 
$C A \operatorname{E} E$

GAI VILLAGE

NRC's client had donated some land for the construction of a Mosque in Gai village, in Kama District of Nangarhar province in 1996 under the Taliban regime.

This land was then illegally sold by the then Head of the District, Molawey Kafayet, to another man, Ehasanullah, who built three shops on the land. NRC's client appealed to the Provincial Administrator who ordered that the construction of the Mosque should go ahead. However, this decision was not implemented before the fall of the Taliban regime. In 2003, the man appealed to NRC's Jalalabad ILAC for help.

In April 2003, NRC's legal counselors met with the commander of the District who agreed with their client's case and prepared a letter for the Governor. NRC's legal counselors met with the Governor's office in May and June 2003 and an instruction

was sent to the Head of the District ordering him to cooperate with NRC's legal counselors to try and solve the case.

In December 2003, the legal counselors met the Head of the District discuss the case.

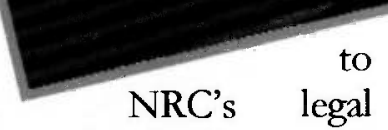
counselors have since attempted to convene a finga to solve it. While the legal issues in this case are straight-forward the authorities are reluctant to pursue this case through the courts as there are a number of powerful people living in the village who are connected to Ehasanullah through their membership of political factions in the Mujahedin. The case remains unresolved at the time of writing.

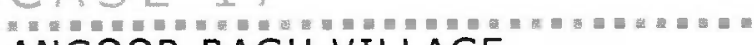
ANGOOR BAGH VILLAGE

NRC's client is from Angoor Bagh village in Jalalabad District of Nangarhar province. In September 2003, his father bought a house that is located in Jalalabad city. The person that he bought it from asked if his brother, who was then living in the house, could stay on for an extra month before he moved out. NRC's client agreed, but after one month another man, named Haji Amran, forcibly occupied the house and refused to leave.

NRC's client contacted the Head of the Police in Sub District Three in Jalalabad city, Commander Selyman Shah, and asked him for help. However, he claims that Commander Selyman Shah refused to intervene because the man occupying the house was a man friend of his. The subsequently produced a document, which claimed that the original owner of the house had leased it to him. NRC's client says that this is a forgery.

A Jinga was held in October 2003 to try and resolve the issue and this decided that the man who was occupying the house should leave it. He has refused to accept this decision and remains in the house. NRC's legal counselors are preparing to convene another finga before they take the case directly to court. The case remains unresolved at the time of writing.

CASE 18
STREAM NUMBER ELEVEN
BEHSOOD DISTRICT (2)
NRC's client claims that his father bought 20
Jerib and 5 Beswa of land in Stream Number 
11, Behsood District of Nangarhar province, from the Governor in 1955. He has the full legal documents for this purchase.

NRC's client left Afghanistan for Pakistan in 1979 and left the land in the care of relatives, who sub-let it to a farmer. In 2003, NRC's client was informed that a number of other people claimed that they had bought the land in 1988 and had documents to prove this. NRC's client says that these documents are forgeries. NRC's legal counselors are investigating the IMLAC records department to find out which documents are genuine.

The case was referred to the Primary Court in 2003 and the client appealed to NRC's Jalalabad ILAC for help. The other party to the dispute has also contacted Jalalabad ILAC and NRC's legal aid centers in Pakistan and have discussed the case with NRC's legal counselors.

While the case was under investigation, the Head of the Police in Behsood District attempted to force NRC's client to surrender the land to a third person, pending the outcome of the court case. This action is completely illegal and so NRC's legal counselors met with the police who promised that that they would not interfere in the case and would respect the decision of the courts. The case remains unresolved at the time of writing.

\section{CHARBAGH SAFA VILLAGE}

NRC's client, and his two brothers, inherited the income of 12 Jeribs of land from their father in Charbagh Safa village, Surkhroad District of Nangarhar province when he died in 1981. The three brothers received an income from the land until 1983 when their grandfather died. At this point their two uncles seized all the land arguing that, under Islamic law, when a son dies before his father any inheritance should go the surviving sons and not be passed on to grandsons. This is a correct reading of Islamic law.

In May 2003, NRC's legal counselors participated in a village /inga, which agreed to grant 12 Beswa of land to NRC's client and his two brothers. This settlement was achieved despite the fact that the uncles were not legally obliged to hand over any of the land in question.

\section{KARAZ KABEER}

\section{STREAM NUMBER TWELVE BEHSOOD DISTRICT}

NRC's client in this case is the representative of 250 families (over 2,000 people) of Karaz Kabeer Stream No.12 of Behsood District. He complains that land adjacent to the village has been captured from them and that this includes the burial ground (Magbard) of the village.

The people of Karaz Kabeer were awarded their land in 1968, in compensation for the loss of their former land in Naghlo Band of Seroby District, Kabul province which was flooded during the construction of Seroby hydro-electric station in 1967. President Zahir Sha granted them new land in Behsood District by a Special Decree and they claim that this included land on a hill adjacent to the village.

In 1991 two men captured the hill next to the village, destroyed the graveyard and began to construct a house. The villagers objected to the construction of the house, pointing out that this directly overlooked the village and would mean a loss of privacy for them. Effectively it meant that the women of the village would not be able to leave their homes without being observed.

Attempts to mediate a settlement through a Jinga failed, but, after the Taliban captured the area, the two men fled to Pakistan. They returned in July 2003 and again sought to occupy the house. The villagers appealed to the Sub Govemor of Behsood District for help in August 2003 and he referred the case to a Jinga. The villagers appealed to NRC for help as the men are linked to a powerful commander in military division No. 7 who reports to Hazrat Ali, the Corps Commander of Nangarhar province.

NRC's counselors registered the case in March 2004 and spoke to both sides in the 
dispute. NRC's counselors also met with the police in charge of Behsood District to discuss the case. The villagers submitted their legal documents to NRC's office and the counselors attempted to arrange a linga in Jalalabad ILAC to resolve the case.

In early April 2004 NRC's counselors attempted to meet with the Sub Governor of Behsood District to attempt to persuade him to attend the finga. The villagers felt that it was important for him to attend this as they were concerned that otherwise the other party to the dispute would not respect the Jingas outcome. The counselors failed to meet the Sub Governor of the District, despite repeated attempts, but were

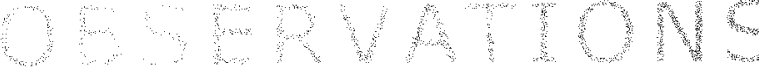

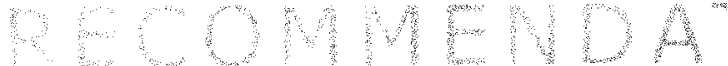 \\ he above cases are only a small, but representative, sample of NRC Jalalabad ILACs current case-load.} From these cases it is possible to make some observations and recommendations.

Land disputes in Eastern Afghanistan are a huge cause of tension and instability. As the number of Afghans returning to the country is expected to rise during the coming two or three years, these tensions are likely to increase. Eastern Afghanistan has experienced the second highest refugee return rates of any part of the country over the last two years and this is making the problem particularly acute.

Although the authorities are genuinely trying to tackle the problem they are greatly hampered by lack of resources and need further financial support from the international community. Land needs to be irrigated to make it productive and there is an urgent need for the authorities to provide more housing, roads, schools, hospitals before people can return to many areas. The issue of land reform also needs to be addressed. eventually able to persuade the head of the police to attend. After another visit to the village Jalalabad ILAC wrote to the other party to the dispute, Commander Hokemran and $\mathrm{Haji}$ Obidullah, requesting a meeting. This took place in Jalalabad ILAC on 8 April at which time all parties agreed to submit the case to a Jinga on 14 April. The Jinga took place in Karaz Kabeer village and all sides agreed to accept the outcome. The finga ruled that the land should be handed back to the people of the village and Commander Hokeram and Haji Obidullah agreed to this in a written document.
The existing mechanisms of law and order remain woefully ill-equipped to deal with the problem of land disputes. There is a widespread distrust of the courts amongst ordinary Afghans and the police often appear to be a part of the problem rather than part of the solution to land disputes.

The absence of the rule of law over the last two and a half years has had a huge political and psychological impact on the population who contrast the current situation unfavorably with the relative stability achieved under the Taliban. The lack of a rule of law since the fall of the Taliban has also created a culture of impunity amongst many commanders and public officials who have come to regard themselves as being 'above the law.' Corruption and intimidation are endemic and have become increasingly entrenched in the system.

There is a real danger that these officials will use their power to legitimize many of the land grabs that have taken place in recent years. Simply providing more resources to the authorities or imposing a 
top-down system of land and property registration will do little to ease the problem and could end up making things worse.

Most Afghans consider that the most effective mechanisms for settling disputes fairly are the customary institutions of Shura and finga. Any attempt to tackle the problem of land disputes must take these informal mechanisms into account. It is clear from NRC's casework, however, that these traditional sources of authority and dispute resolution have also been weakened by the disruption of conflict and displacement and that their judgments do not always accord with human rights principles or Afghanistan's obligations under international law.

As stated above, the overwhelming priority for Afghanistan is the restoration of pcacc and stability and the rule of law. Tackling the problem of land disputes needs to be done in parallel with this process and this should go hand-in-hand with a coherent policy of land reform. There is also a need for far greater analysis of the strengths and weaknesses of Afghanistan's informal justice system. The international community and donors should include this in any strategy for rebulding the capacity of Afghanistan's judicial system. In the short-term NRC would offer a number of specific recommendations:

Judges need to be trained on the current applicable law, and sources of law, governing land and property rights.
- Information about land rights should be disseminated as widely as possible and people should be encouraged to come forward with claims.

Courts should be required to reach decisions in land and property cases within certain time-limits - as it is widely believed that many delays are due to comuption or intimidation of judges and public officials - and those that fail to do so should be called to account.

* A 'name and shame' policy should be adopted towards commanders and public officials who misuse their powers. Where commanders are refusing to implement or abide by the official decisions of the courts or administrative authorities, or where judges or public officials are making blatantly biased decisions the individuals should be exposed and, where possible, removed from office.

All land registration exercises should be closely monitored to guard against comption and land-grabbing. This applies both to govemment and provincial land registration and mapping exercises as well as proposals for land registration emanating from the international community.

The decisions of Sham and firyz need to be monitored more dosely and, where these can be shown to be fair, they should be registered officially. A human rights training program aimed at the members of Shm and fima should be introduced. 

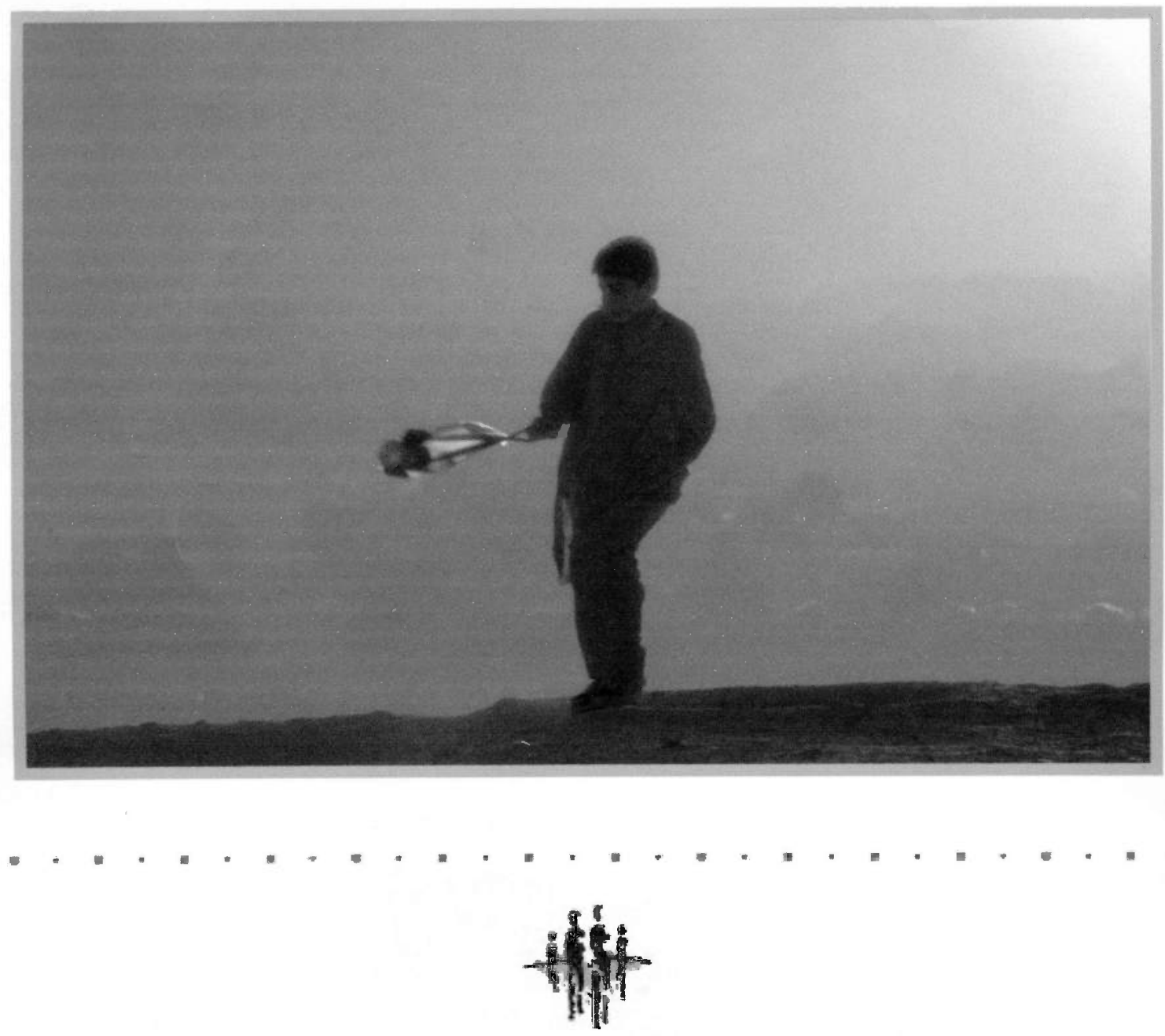

NORWEGIAN REFUGEE COUNCIL

\section{LEGAL AID PROJECT}

House No.570, between street $8 / 9$, Qala-e-Fatullha

Kabul - Afghanistan

$+93(0) 70284365$

nrc@ceretechs.com

http://www.nrc.no

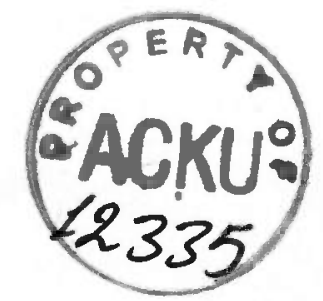

